\title{
Pembelajaran Bilingual English for Health Berbasis Bahasa Ibu Bagi Guru PAUD Kota Semarang
}

\author{
Ririn Ambarini, Eva Ardiana Indrariani, Ayu Dian Zahraini \\ Universitas PGRI Semarang \\ ririnambarini@upgris.ac.id
}

Submitted: 5 February 2019. Revised: 8 July 2019. Accepted: 27 July 2019

\section{Key word:}

Learning;

Bilingual; lesson

plan; English for

Health; Mother

Tongue

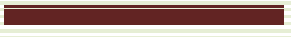

Kata Kunci

Pembelajaran;

Bilingual; RPP;

English for

Health; Bahasa

Ibu

\section{Abstract}

Implementation of Community Service is carried out in the form of training activities, workshops and field assistance which is divided into four stages in a systematic and continuous manner. In phase I, material will be delivered which includes: (1) Social and Emotional Health; (2) Nutrition and Fitness; (3) Safety, first Aid, and Injury Prevention; and (4) Disease Prevention and Control, (5) Techniques for preparing lesson plans on bilingual learning in health and nutrition education for early childhood that can be applied during the teaching and learning process for approximately 30 minutes, at least once a week. Phase II is training in preparing RPP about bullying. Phase III is Peer Teaching Practice and Phase IV is the Discussion and Self-reflection stage. The main aim of this Community Service is that PAUD teachers and staff can implement and implement bilingual learning programs in health and nutrition education in their respective schools so that PAUD teachers and staff can provide healthy living choices while also teaching children to make healthy life choices for them. . The methods used in the implementation of this program include training, lectures, questions and answers, and discussions, teaching practices and worksheets that are the output of participants from this training.

\section{Abstrak}

Pelaksanaan Pengabdian Kepada Masyarakat ini dilakukan dalam bentuk kegiatan pelatihan, workshop dan pendampingan lapangan yang terbagi dalam empat tahapan secara sistematis dan berkesinambungan. Pada tahap I akan dilakukan penyampaian materi yang meliputi: (1) Social and Emotional Health; (2) Nutrition and Fitness; (3) Safety, first Aid, and Injury Prevention; and (4) Disease Prevention and Control, (5) Teknik penyusunan RPP tentang pembelajaran bilingual pendidikan kesehatan dan gizi untuk anak usia dini yang bisa diterapkan selama proses belajar mengajar selama kurang lebih 30 menit, minimal sekali dalam seminggu. Tahap II adalah pelatihan menyusun RPP tentang bullying. Tahap III adalah Praktik Peer Teaching dan Tahap IV yaitu tahap Diskusi dan Refleksi diri. Tujuan utama Pengabdian ini guru dan staf PAUD dapat melaksanakan dan menerapkan program-program pembelajaran bilingual pendidikan kesehatan dan gizi di sekolah mereka masing masing sehingga guru dan staf PAUD dapat memberikan pilihan-pilihan hidup sehat sekaligus mengajari anak-anak untuk membuat pilihan hidup sehat bagi mereka. Metode yang digunakan dalam pelaksanaan program ini meliputi 
pelatihan, ceramah, tanya jawab, dan diskusi, praktek mengajar serta lembar kerja yang merupakan output peserta dari pelatihan ini.

\section{PENDAHULUAN}

Dalam pandangan agama, anak adalah amanah Allah SWT. Dengan predikat itu layak bagi kita menjaga dan memeliharanya, serta kita wajib memahami anak sebagai bagian dari penentu masa depan kehidupan bangsa, oleh karena itu sudah sepantasnya anak mendapat prioritas utama dalam perlindungan harga diri dan hidupnya.

Anak merupakan individu yang belum matang secara fisik mental maupun sosial. Dalam arti kata lain anak merupakan makhluk yang masih tumbuh dan berkembang. Oleh karena itu kondisi anak masih rentan dan masih tergantung pada orang dewasa. Perkembangan masyarakat suatu bangsa terutama peran serta sumber daya manusia adalah untuk menciptakan kerukunan, kesejahteraan kehidupan, serta banyak keluarga yang karena berbagai faktor tidak mampu secara mandiri memenuhi kebutuhan dan mengasuh anak. Di samping itu berbagai peraturan perundang-undangan telah menunjukkan bahwa negara melindungi setiap warga negara dan menjamin hakhak anak dalam tumbuh berkembang serta berpartisipasi sesuai kemampuannya (Van Roekel, 2008).
Semua anak harus memiliki kesempatan untuk belajar. Namun, kapasitas untuk sukses berkurang jika siswa tidak hadir atau terganggu oleh masalah kesehatan yang dikarenakan oleh perilaku yang tidak sehat atau situasi berbahaya. Oleh karena itu pendidikan kesehatan memiliki peran yang sangat signifikan untuk membentuk pribadi yang sehat. Pendidikan Kesehatan akan berhasil dengan baik apabila diimplementasikan melaui proses kolaborasi antara keluarga, sekolah, dan masyarakat (Feinstein, L. Et.al. 2006). Siswa yang memperoleh pendidikan kesehatan akan memiliki kapasitas untuk mendapatkan, menafsirkan, dan menggunakan informasi kesehatan dan keterampilan dasar untuk meningkatkan kesehatan individu. Instruksi kesehatan dalam implementasi pendidikan kesehatan di sekolah harus berfokus pada kesehatan dan kesejahteraan siswa dan harus menjadi bagian integral dan konsisten dari total program sekolah (Chen \& Li, 2009). Instruksi yang dimulai saat anak-anak masih muda yaitu mulai dari tingkat pendidikan anak usia dini atau PAUD dan berlanjut ke kehidupan remaja akan memperkuat perilaku positif yang harus dipertahankan sepanjang masa dewasa. 
Bayangkan sebuah sekolah di mana semua siswa fit, sehat, dan siap untuk belajar; dimana semua siswa memiliki keterampilan penting untuk menjaga dan meningkatkan kualitas hidup sehat dan kehidupan produktif. Bayangkan bahwa orang muda berhasil menerapkan keterampilan yang mereka pelajari melalui pendidikan kesehatan dan mereka terapkan dalam kehidupan nyata, yaitu situasi menantang sepanjang masa remaja mereka dan Dewasa. Pada saat banyak kekuatan menekan siswa untuk mengambil keputusan Yang bisa membahayakan kesejahteraan mereka, keterampilan dan pengetahuan terkait kesehatan menjadi bagian penting untuk memastikan setiap anak siap untuk sukses. Untuk mengidentifikasi secara jelas apa yang seharusnya diketahui dan dapat dilakukan siswa agar dapat mengidentifikasi dengan tepat serta menjalani hidup sehat, penting untuk merancang model pembelajaran kesehatan untuk anak usia dini yang bisa diintegrasikan dengan pembelajaran bahasa untuk meningkatkan kemampuan komunikasi sekaligus ketrampilan sosial anak (Evers, 2011).

Pendidikan kesehatan untuk anak usia dini harus diimplementasikan dalam bentuk pembelajaran yang melibatkan atau yang berhubungan langsung dengan pengalaman anak. Dalam hal ini pembelajaran tentang kesehatan harus disampaikan dalam suatu cara dimana siswa atau anak dapat memperoleh, menginterpretasikan, dan menerapkan informasi kesehatan dasar dalam kehidupan sehari-hari mereka sehingga dapat meningkatkan kesehatan pribadi mereka. Agar menjadi anak yang melek akan pentingnya kesehatan, siswa harus didorong untuk menjadi pembelajar yang mandiri dimana pada saat yang sama mereka juga belajar bagaimana memahami bagaimana menjaga kesehatan dan bagaimana mencegah datangnya penyakit. Anak anak harus didorong untuk dapat menggunakan literasi, ketrampilan berhitung, dan ketrampilan berpikir kritis untuk mengumpulkan, mengoleksi, dan menerapkan informasi kesehatan karena kebutuhan dan prioritas mereka akan selalu berubah sepanjang hidup mereka. Mereka juga perlu diajarkan bagaimana menggunakan ketrampilan sosial dan komunikasi dalam suatu hubungan satu dengan yang lain sehingga mereka akan belajar bagaimana belajar tentang orang lain dan dari orang lain (UNESCO, 2014).

$$
\text { Dengan melek kesehatan, }
$$
keterampilan manajemen diri yang sehat, dan promosi kesehatan, maka pendidikan kesehatan yang komprehensif akan mengajarkan konsep kesehatan mendasar, mempromosikan kebiasaan dan perilaku 
yang meningkatkan kesehatan dan kesejahteraan, dan memandu upaya membangun keluarga, hubungan, sekolah, dan masyarakat yang sehat (Driscoll, 1999).

Oleh karena itu guru PAUD membutuhkan pelatihan tentang pembelajaran terkait dengan area pendidikan kesehatan dalam bentuk kerangka untuk pembelajaran anak usia dini. Pelatihan tersebut akan memberikan berbagai macam kegiatan pembelajaran dimana siswa akan memperoleh pengetahuan dan belajar bagaimana mengembangkan perilaku, sikap positif dan ketrampilan yang sangat penting untuk mengembangkan kemampuan dalam mengambil keputusan terkait dengan kesehatan yang sangat penting terkait dengan kemampuan menerapkan tanggungjawab sepanjang masa kehidupan dimana perkembangan ketrampilan kesehatan sangat dibutuhkan untuk meningkatkan kualitas kehidupan (Tominey, 2012).

Bahasa adalah kunci utama dalam komunikasi dan pemahaman di dalam kelas. Pembelajaran di kelas yang disampaikan secara bilingual berbasis bahasa Ibu akan memudahkan guru dan siswa untuk berinteraksi secara natural dan menegosiasikan makna bersama, menciptakan partisipasi dalam lingkungan pembelajaran yang kondusif menuju pembelajaran kognitif seiring dengan perkembangan kemampuan linguistik anak (Benson, 2005). Pembelajaran bilingual menggunakan bahasa Ibu sebagai basis dalam proses pembelajaran karena bahasa ibu adalah alat untuk mengembangkan kualitas pendidikan dengan membangun pengetahuan dan pengalaman baik guru maupun peserta didik. Sedangkan pembelajaran bilingual itu sendiri penting karena sebagai alat untuk mempromosikan kesetaraan gender dan sosial dan sebagai elemen kunci dari masyarakat yang mempunyai keberagaman bahasa (Ball, 2011).

Program pelatihan dan pengembangan pembelajaran kesehatan untuk anak usia dini didesain dan dikemas dalam bentuk pembelajaran bilingual karena pembelajaran bilingual yang dimulai sejak usia dini banyak menunjukkan manfaat. Yang pertama adalah bahwa anak yang mempunyai kemampuan bahasa bilingual akan lebih mudah memahami konsep-konsep Matematika, dan soal soal cerita Matematika (Zelasko \& Antunez, 2000). Selanjutnya anak yang mempunyai kemampuan bilingual juga akan lebih mudah mengembangkan ketrampilan berpikir yang sangat kuat (Kessler \& Quinn, 1980). Lebih lanjut, anak juga akan 
dapat menggunakan kemampuan logika mereka lebih maksimal (Castro, Ayankoya, \& Kasprzak, 2011). Dan yang lebih penting lagi adalah bahwa kemampuan bahasa bilingual akan melatih anak untuk meningkatkan kemampuan mereka dalam membuat keputusan, fokus dalam berbagai hal, serta kemampuan mengingat (Bialystok, 2001). Oleh karena itu, tim pengabdi merumuskan program kemitraan masyarakat berupa pelatihan dan pengembangan pembelajaran bilingual English for Health berbasis bahasa Ibu bagi guru PAUD di kota Semarang. Dengan berdasar bahasa Ibu, maka pengabdi juga ingin memaksimalkan kemampuan anak dalam komunikasi menggunakan bahasa Ibu yang secara langsung maupun tidak langsung dapat membantu anak dalam penguasaan bahasa bilingual mereka.

Dalam program pelatihan dan pengembangan pembelajaran bilingual English for Health berbasis bahasa ibu bagi guru PAUD di Kota Semarang, pendidik anak usia dini akan mendapatkan pelatihan untuk dapat mengajar, memberikan model, dan mempersiapkan anak-anak untuk memahami konsepkonsep terkait dengan menjaga kesehatan dan mencegah penyakit sehingga anak usia dini mendapatkan pengetahuan bagaimana meningkatkan kesehatan tubuh. Dalam pelatihan ini, pendidik atau guru PAUD juga akan mengajari anak usia dini untuk mendemonstrasikan kemampuan menggunakan pengetahuan tentang nutrisi dan kebugaran, ketrampilan-ketrampilan, dan strategi strategi untuk meningkatkan gaya hidup sehat. Dengan kata lain, pendidik anak usia dini juga dapat mengajarkan anak-anak bagaimana menjaga kebersihan dan membiasakan hidup sehat.

Permasalahan yang dihadapi oleh mitra TK Islam Tunas Melati Semarang dan TK Amanah Al Kafalah Semarang adalah pembelajaran konsep esensi, menganalisa pengaruh, mengembangkan komunikasi interpersonal, kemampuan mengambil keputusan, melatih perilaku yang dapat meningkatkan kesehatan dalam empat konten area pembelajaran kesehatan:

1. Social and Emotional Health; (Kesehatan Emosi dan Sosial)

2. Nutrition and Fitness; (Kebugaran dan Nutrisi)

3. Safety, first Aid, and Injury Prevention; and (Keamanan, Pertolongan Pertama, dan Mencegah cedera/kecelakaan kecil)

4. Disease Prevention and Control. (mengontrol dan menjaga kesehatan supaya tidak mudah jatuh sakit) 
5. Mempelajari dan membuat RPP tentang pembelajaran bilingual English for Health berbasis bahasa ibu dari ke empat konten area yang bisa diterapkan selama proses belajar mengajar selama kurang lebih 30 menit, minimal sekali dalam seminggu dengan menggunakan materi poster, puppet role-play, story times, dan demonstration yang dikemas dalam pembelajaran bilingual berbasis bahasa Ibu.

Berkaitan dengan hal tersebut diatas, maka dipandang perlu adanya penataran, pelatihan, pembimbingan dan pendampingan tentang pembelajaran bilingual English for Health berbasis bahasa ibu untuk guru PAUD di Kota Semarang. Dimana program pelatihan ini tidak hanya memberikan penyuluhan bagi guru PAUD untuk mengembangkan ketrampilan motorik anak, kesehatan dan gizi, akan tetapi juga mengembangkan ketrampilan bahasa bilingual anak mulai dari rentang 20\% hingga 50\% persentase pelibatan bahasa Inggris dalam pelatihan dan pengembangan pembelajaran bilingual English for Health berbasis bahasa ibu ini. Oleh karena itu, diperlukan adanya forum untuk memfasilitasi kegiatan tersebut bagi guru, khususnya guru PAUD di kota Semarang.
Target kegiatan ini adalah guru dan staf di TK Islam Tunas Melati Semarang dan TK Amanah Al Kafalah Semarang. Pengembangan motorik anak yang sejalan dengan pengembangan kemampuan komunikasi anak melalui pembelajaran bilingual English for Health berbasis bahasa Ibu akan sukses apabila melibatkan pendidikan, persiapan, dan kerja tim. Program pembelajaran bilingual English for Health berbasis bahasa Ibu untuk mitra TK Islam Tunas Melati Semarang dan TK Amanah Al Kafalah Semarang akan memberikan wacana-wacana khusus, stategi-strategi, kegiatan-kegiatan, serta sumber-sumber yang merujuk pada pengembangan motorik anak sekaligus pengembangan kemampuan komunikasi anak dalam bentuk perangkat pembelajaran dan penyuluhan kesehatan dan gizi di bidang kesehatan.

Mitra TK Islam Tunas Melati mempunyai guru dan staff yang berjumlah 8 orang sedangkan TK Amanah Al Kafalah mempunyai guru dan staff yang berjumlah 8 orang. Setiap peserta diharapkan berpartisipasi aktif dalam program pelatihan dan pengembangan pembelajaran bilingual English for Health berbasis bahasa Ibu dalam setiap tahap materi yang disampaikan. Oleh karena itu pendampingan perlu dilakukan dari tahap materi yang pertama hingga yang terakhir 
yaitu pembuatan RPP tentang pembelajaran bilingual English for Health berbasis bahasa Ibu yang nantinya diharapkan dapat diterapkan selama proses belajar mengajar di Sekolah yaitu di dalam maupun di luar kelas.

Pengetahuan dan keterampilan kesehatan dasar perlu diajarkan mulai dari masa taman kanak-kanak. Kurikulum berurutan yang terencana membahas berbagai topik dengan tingkat kompleksitas yang meningkat sesuai dengan tingkat perkembangan siswa. Program semacam itu memastikan bahasan area kesehatan yang menyeluruh dan seimbang, dan keberhasilannya bergantung pada guru terampil yang siap menyesuaikan diri dengan memasukkan topik kesehatan yang sedang trend ataupun yang terbaru. Dalam pelatihan ini ditawarkan berbagai aktivitas di kelas terkait pendidikan kesehatan yang komprehensif mengajarkan konsep dan keterampilan kesehatan dasar bagi siswa agar dapat menumbuhkan kebiasaan dan perilaku sehat bagi diri sendiri dan orang lain melalui pengajaran pendidikan kesehatan, pendidikan jasmani, dan pendidikan keluarga secara terpadu berurutan yang disampaikan secara bilingual dalam berbagai kegiatan permainan yang menarik dan terkoordinasi di taman kanak-kanak.

\section{METODE}

Pengabdian pada masyarakat telah dilakukan dalam bentuk kegiatan pelatihan, workshop dan pendampingan lapangan yang terbagi dalam 5 (lima) tahapan secara sistematis dan berkesinambungan. Tiap tahapan telah diikuti oleh guru-guru mitra TK Islam Tunas Melati Semarang dan TK Amanah Al Kafalah Semarang dengan jumlah peserta 16 guru dan staff.

Tahapan kegiatan yang telah berlangsung adalah sebagai berikut:

1. Tahap I (Tahap Penyampaian Materi) Pada tahap ini dilakukan penyampaian materi yang meliputi Pemahaman pembelajaran konsep esensi, menganalisa pengaruh, mengembangkan komunikasi interpersonal, kemampuan mengambil keputusan, melatih perilaku yang dapat meningkatkan kesehatan dalam empat konten area pembelajaran kesehatan:

a. Social and Emotional Health; (Kesehatan Emosi dan Sosial)

b. Nutrition and Fitness; (Kebugaran dan Nutrisi)

c. Safety, first Aid, and Injury Prevention; and (Keamanan, Pertolongan Pertama, dan 
Mencegah cedera/kecelakaan kecil)

d. Disease Prevention and Control. (mengontrol dan menjaga kesehatan supaya tidak mudah jatuh sakit)

e. Mempelajari dan membuat RPP tentang pembelajaran bilingual English for Health berbasis bahasa ibu dari ke empat konten area yang bisa diterapkan selama proses belajar mengajar selama kurang lebih 30 menit, minimal sekali dalam seminggu dengan menggunakan materi poster, puppet role-play, story times, dan demonstration yang dikemas dalam pembelajaran bilingual berbasis bahasa Ibu.

Materi tersebut disampaikan dalam bentuk ceramah, tanya jawab, pelatihan, dan diakhiri dengan penugasan penyusunan RPP tentang pembelajaran bilingual English for Health berbasis bahasa Ibu serta peer teaching sebagai simulasi dan sekaligus sebagai implementasi dari RPP tentang pembelajaran bilingual English for Health berbasis bahasa Ibu sesuai dengan buku panduan dan link pembelajaran yang diberikan oleh tim pengabdi. Kegiatan ini akan dilaksanakan di kampus TK Islam
Tunas Melati Semarang dan juga kampus

TK Amanah Al Kafalah Semarang.

2. Tahap II (Tahap Pelatihan)

Pada tahap ini, peserta berlatih mempraktekkan dan mengembangkan contoh-contoh RPP tentang pembelajaran bilingual English for Health berbasis bahasa Ibu yang sudah disiapkan oleh tim pengabdi sebagai tindak lanjut dari tahap pertama. Diharapkan dalam pelatihan ini, guru dapat mempraktekkan dan mengimplemantasikan RPP tentang pembelajaran bilingual English for Health berbasis bahasa Ibu sesuai dengan buku panduan dan link pembelajaran yang diberikan oleh tim pengabdi. Selanjutnya, praktek dan implementasi RPP dapat diterapkan dalam latihan peer teaching.

3. Tahap III ( Tahap Praktik Peer Teaching)

Setiap guru pada tahap ini melakukan praktek pembelajaran bilingual English for Health berbasis bahasa Ibu sesuai dengan buku panduan dan link pembelajaran yang diberikan oleh tim pengabdi dengan rekan mereka sendiri dalam bentuk peer teaching. Teknik pembimbingan dan pendampingan dilakukan untuk mengetahui tingkat pemahaman guru terhadap bagaimana penerapan RPP yang diterapkan dalam 
bentuk pembelajaran yang

diintegrasikan dalam proses

pengajaran di kelas melalui peer

teaching.

4. Tahap IV (Tahap Praktik Classroom

\section{Practice)}

Setiap guru pada tahap ini adalah kelanjutan dari tahap sebelumnya dimana guru melakukan praktek pembelajaran bilingual English for Health and berbasis bahasa Ibu sesuai dengan buku panduan dan link pembelajaran yang diberikan oleh tim pengabdi dengan rekan mereka sendiri di kelas mereka masing-masing. Teknik pembimbingan dan pendampingan dilakukan untuk mengetahui tingkat pemahaman guru terhadap bagaimana penerapan RPP yang diterapkan dalam bentuk pembelajaran yang diintegrasikan dalam proses pengajaran di sekolah mereka sendiri, yakni dalam bentuk:

a) Tim pelaksana pengabdian pada masyarakat melakukan pemantauan dan evaluasi ke sekolah-sekolah tempat praktik guru menerapkan pembelajaran tentang pembelajaran bilingual English for Health berbasis bahasa Ibu sesuai dengan buku panduan dan link pembelajaranyang diberikan oleh tim pengabdi, b) Melakukan bimbingan dan pendampingan di luar sekolah seperti melalui telepon dan e-mail,

c) Guru dapat melakukan konsultasi dengan tim pelaksana (instruktur) di kampus Universitas PGRI Semarang jika diperlukan,

5. Tahap V ( Tahap Diskusi \& Refleksi Diri)

Pada tahap ini adalah tahap diskusi dan refleksi diri sekaligus sharing dari masing-masing guru tentang kelebihan dan juga kekurangan terhadap pembelajaran pembelajaran bilingual English for Health berbasis bahasa Ibu sesuai dengan buku panduan dan link pembelajaranyang diberikan oleh tim pengabdi sebagai bagian dari pelatihan dan pengembangan pembelajaran English for Health berbasis bahasa Ibu yang diterapkan di sekolah mereka. Bimbingan dan pendampingan pada tahap ini dilakukan di kampus TK Islam Tunas Melati Semarang dan juga kampus TK Amanah Al Kafalah Semarang.

\section{HASIL DAN PEMBAHASAN}

Program pengabdian masyarakat yang dilakukan oleh tim pengabdi adalah pelatihan dan pengembangan pembelajaran bilingual English for Health berbasis bahasa Ibu bagi guru PAUD di Kota 
Semarang yang menjadi mitra yaitu TK Islam Tunas Melati Semarang dan TK Amanah Al Kafalah Semarang. Dengan adanya pelatihan ini diharapkan warga sekolah dalam hal ini di lingkungan PAUD akan lebih meningkatkan kesehatan dan gizi anak usia dini yang meliputi empat konten area yaitu:n 1) Social and Emotional Health (Kesehatan Emosi dan Sosial); (2) Nutrition and Fitness (Kebugaran dan Nutrisi); (3) Safety, first Aid, and Injury Prevention (Keamanan, Pertolongan Pertama, dan Mencegah cedera/kecelakaan kecil), and; (4) Disease Prevention and Control (mengontrol dan menjaga kesehatan supaya tidak mudah jatuh sakit).

\section{Sangatlah penting berbagi} pemahaman kepada lingkungan PAUD tentang segala hal yang terkait dengan tumbuh kembang anak dalam hal ini kesehatan dan gizi yang meliputi empat konten area dimana cakupan yang pertama adalah Social and Emotional Health atau kesehatan emosi dan sosial dimana diharapkan anak akan mengembangkan kemampuan untuk membentuk hubungan yang kuat dengan yang lain, mengekspresikan dan mengontrol emosi, mengeksplorasi dunia di sekitar mereka dan meningkatkan kemampuan problemsolving. Area cakupan yang kedua adalah Nutrition and Fitness atau Gizi dan kebugaran diharapkan guru PAUD dapat lebih bervariasi dan tepat sasaran dalam menerapkan topik ini dalam pembelajaran sehingga gizi dan kebugaran anak usia dini pun akan meningkat yang akan meningkatkan pula perkembangan kecerdasan anak. Untuk topik yang ketiga adalah Safety, first Aid, and Injury Prevention atau Keamanan, Pertolongan Pertama, dan Mencegah cedera/kecelakaan kecil dimana tujuan dari pembelajaran ini untuk anak usia dini adalah meningkatkan kemampuan mereka dalam menjaga diri dan mampu mengambil keputusan apa yang harus dilakukan ketika menemukan barang barang yang membahayakan ataupun saat terluka. Dan cakupan topic yang terakhir adalah Disease Prevention and Control atau mengontrol dan menjaga kesehatan supaya tidak mudah jatuh sakit dimana anak diperkenalkan bagaimana menjaga kesehatan dan apa efek yang akan terjadi apabila mereka tidak berusaha untuk menjaga kesehatan badan mereka.

Dalam pelatihan ini ada sesi tanya jawab atau sharing, pengayaan, pembuatan RPP tentang pembelajaran bilingual English for Health berbasis bahasa ibu dari ke empat konten area: 1) Social and Emotional Health (Kesehatan Emosi dan Sosial); (2) Nutrition and Fitness (Kebugaran dan Nutrisi); (3) Safety, first Aid, and Injury 
Prevention (Keamanan, Pertolongan

Pertama, dan Mencegah cedera/kecelakaan kecil); dan (4) Disease Prevention and Control (mengontrol dan menjaga kesehatan supaya tidak mudah jatuh sakit).

Tahapan kegiatan yang sudah dan sedang berlangsung adalah sebagai berikut:

1. Tahap I (Tahap Penyampaian Materi) Pada tahap ini akan dilakukan penyampaian materi yang meliputi:

a. Social and Emotional Health (Kesehatan Emosi dan Sosial)

b. Nutrition and Fitness (Kebugaran dan Nutrisi)

c. Safety, first Aid, and Injury Prevention (Keamanan,

Pertolongan Pertama, dan Mencegah cedera/kecelakaan kecil), dan;

d. Disease Prevention and Control (mengontrol dan menjaga kesehatan supaya tidak mudah jatuh sakit)

e. Tehnik penyusunan RPP tentang pembelajaran bilingual English for Health berbasis bahasa ibu dari ke empat konten area yang bisa diterapkan selama proses belajar mengajar selama kurang lebih 30 menit, minimal sekali dalam seminggu dengan menggunakan materi poster, puppet role-play, story times, dan demonstration yang dikemas dalam pembelajaran bilingual berbasis bahasa Ibu.

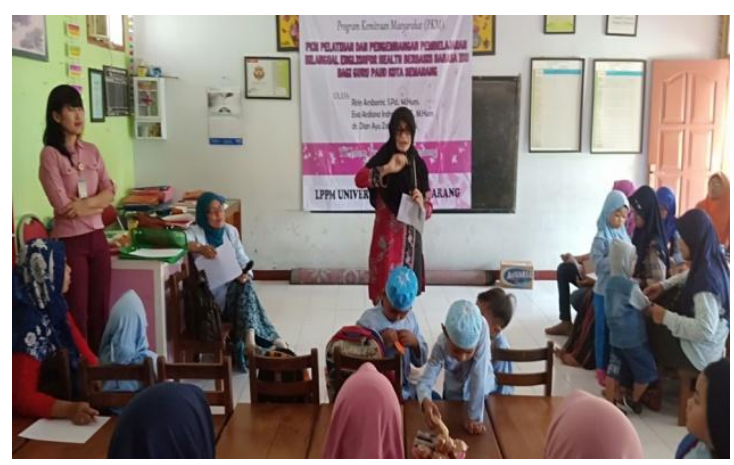

Gambar 1. Penyampaian materi tentang bahasa Ibu

Materi tersebut disampaikan dalam bentuk ceramah, tanya jawab, pelatihan, dan diakhiri dengan penugasan penyusunan RPP tentang pembelajaran bilingual English for Health berbasis bahasa ibu dari ke empat konten area yang bisa diterapkan selama proses belajar mengajar selama kurang lebih 30 menit, minimal sekali dalam seminggu dengan menggunakan materi poster, puppet roleplay, story times, dan demonstration yang dikemas dalam pembelajaran bilingual berbasis bahasa Ibu.

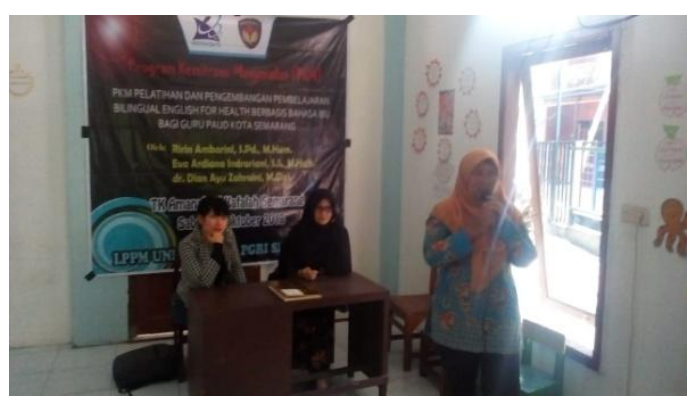


Gambar 2. Penyampaian Materi

Pembelajaran bilingual

Hasil dari implementasi tahap I yaitu tahap penyampaian materi pembelajaran bilingual English for Health berbasis bahasa ibu dari ke empat konten area: 1) Social and Emotional Health (Kesehatan Emosi dan Sosial); (2) Nutrition and Fitness (Kebugaran dan Nutrisi); (3) Safety, first Aid, and Injury Prevention (Keamanan, Pertolongan Pertama, dan Mencegah cedera/kecelakaan kecil); dan (4) Disease Prevention and Control (mengontrol dan menjaga kesehatan supaya tidak mudah jatuh sakit), para guru PAUD di TK Islam Tunas Melati sangat antusias berbagi pengetahuan dan pengalaman tentang masing masing materi yang didiskusikan. Mereka juga sangat antusias dalam sesi Tanya jawab terkait dengan topic pelatihan di ke empat konten area dan merasakan manfaat tambahan pengetahuan dari yang sudah mereka miliki tentang Kesehatan Emosi dan Sosial, Kebugaran dan Nutrisi, Keamanan, Pertolongan Pertama, dan Mencegah cedera/kecelakaan kecil, mengontrol dan menjaga kesehatan supaya tidak mudah jatuh sakit. Pada sesi diskusi dan Tanya jawab, para guru mengutarakan ide mereka tentang segala pointer yang diajukan oleh tim pengabdi yang selanjutnya memberikan sesi pengayaan penambahan dari ide ide yang sudah diutarakan oleh para guru PAUD tentang apa dan bagaimana alternatif kegiatan pembelajaran terkait dengan ke empat konten area untuk dapat diterapkan di kelas.

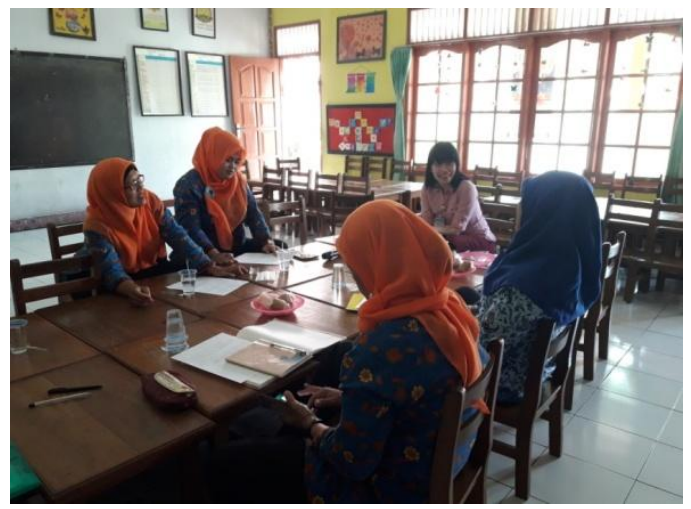

Gambar 3. Diskusi dengan guru

Begitu juga halnya dengan hasil dari implementasi tahap I di TK Amanah Al Kafalah Semarang meliputi tahap penyampaian materi pembelajaran bilingual English for Health berbasis bahasa ibu dari ke empat konten area: 1) Social and Emotional Health (Kesehatan Emosi dan Sosial); (2) Nutrition and Fitness (Kebugaran dan Nutrisi); (3) Safety, first Aid, and Injury Prevention (Keamanan, Pertolongan Pertama, dan Mencegah cedera/kecelakaan kecil); dan (4) Disease Prevention and Control (mengontrol dan menjaga kesehatan supaya tidak mudah jatuh sakit), para guru PAUD di TK Amanah Al Kafalah menunjukkan antusias yang cukup tinggi 
dalam berbagi pengetahuan dan pengalaman tentang masing masing materi yang didiskusikan. Para guru PAUD di TK Amanah Al Kafalah juga sangat antusias dalam melontarkan dan memberikan argumen-argumen berdasarkan pengetahuan dan pengalaman mereka di sesi Tanya jawab terkait dengan topic pelatihan di ke empat konten area dan merasakan manfaat tambahan pengetahuan dari yang sudah mereka miliki tentang Kesehatan Emosi dan Sosial, Kebugaran dan Nutrisi, Keamanan, Pertolongan Pertama, dan Mencegah cedera/kecelakaan kecil, mengontrol dan menjaga kesehatan supaya tidak mudah jatuh sakit. Pada sesi diskusi dan Tanya jawab, mereka menjabarkan banhyak hal tentang penerapan English for Health di kelas dengna segala kelebihan dan kekurangannya pada saat belum mendapatkan pelatihan. Namun pada intinya materi pelatihan sangat memberikan banyak masukan bagaimana mengemas pendidikan kesehatan di dalam kelas, sehingga pada sesi Tanya jawab pada saat pelatihan, para guru mengutarakan ide mereka tentang segala pointer yang diajukan oleh tim pengabdi yang selanjutnya memberikan sesi pengayaan penambahan dari ide ide yang sudah diutarakan oleh para guru PAUD di TK Amanah Al Kafalah tentang apa dan bagaimana alternatif kegiatan pembelajaran terkait dengan pendidikan kesehatan yang meliputi empat konten area untuk dapat diterapkan di kelas.

\section{Tahap II (Tahap Pelatihan)}

Pada tahap ini, peserta berlatih menyusun RPP tentang pembelajaran bilingual English for Health berbasis bahasa ibu dari ke empat konten area yang bisa diterapkan selama proses belajar mengajar selama kurang lebih 30 menit, minimal sekali dalam seminggu dengan menggunakan materi poster, puppet roleplay, story times, dan demonstration yang dikemas dalam pembelajaran bilingual berbasis bahasa Ibu yang kemudian untuk implementasi RPP tentang pembelajaran bilingual English for Health berbasis bahasa ibu dari ke empat konten area tersebut dapat diterapkan dalam latihan peer teaching.

Hasil dari penerapan tahap kedua yaitu tahap pelatihan penyusunan RPP yang sudah di sesuaikan dengan format sekolah TK Islam Tunas Melati Semarang, para guru menunjukkan kreatifitas yang memuaskan dalam menuangkan ide menyusun RPP berdasarkan pembelajaran bilingual English for Health berbasis bahasa ibu dari ke empat konten area. 


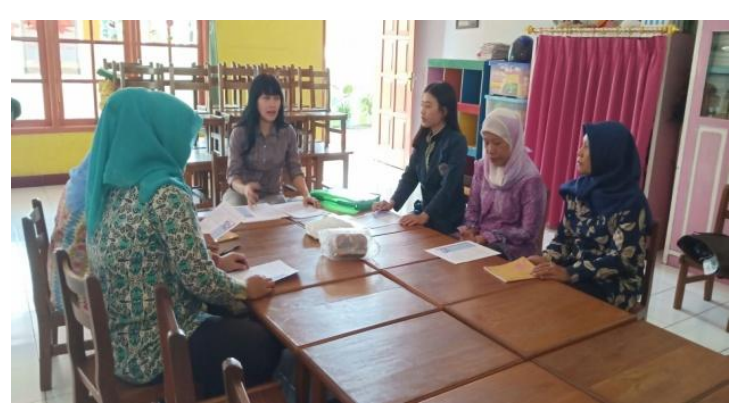

Gambar 4. Pelatihan Pembuatan RPP

Penerapan tahap II di TK Amanah

Al Kafalah yang ditujukan untuk guru PAUD di sekolah tersebut menunjukkan hasil yang memuaskan. Hasil dari penerapan tahap kedua yaitu tahap pelatihan penyusunan RPP yang sudah di sesuaikan dengan format sekolah TK Amanah Al Kafalah Semarang, para guru menunjukkan kreatifitas yang memuaskan dalam menuangkan ide menyusun RPP berdasarkan pembelajaran bilingual English for Health berbasis bahasa ibu dari ke empat konten area yang telah disepakati bersama dengan rujukan contoh contoh kegiatan yang sudah disesuaikan dengan usia dan kebutuhan anak usia dini.

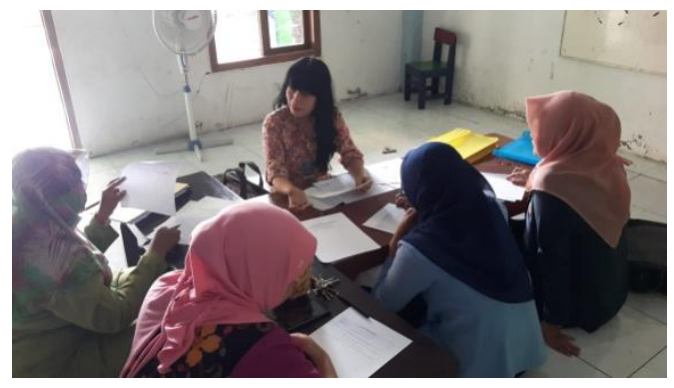

Gambar 5. Review RPP yang dibuat

\section{Tahap III ( Tahap Praktik Peer Teaching)}

Setiap guru pada tahap ini melakukan praktek pembelajaran bilingual English for Health berbasis bahasa ibu dari ke empat konten area dengan rekan mereka sendiri dalam bentuk peer teaching. Teknik pembimbingan dan pendampingan dilakukan untuk mengetahui tingkat pemahaman guru terhadap bagaimana penerapan RPP tentang pembelajaran bilingual English for Health berbasis bahasa ibu dari ke empat konten area yang diterapkan dalam bentuk pembelajaran tentang pembelajaran bilingual English for Health berbasis bahasa ibu dari ke empat konten area yang diintegrasikan dalam proses pengajaran di kelas melalui peer teaching.

Hasil dari implementasi tahap tiga sebagai kelanjutan dari tahap penyusunan RPP adalah Praktik Peer Teaching dimana para guru praktik mengajar sebagai simulasi sebelum mereka menerapkkannya di kelas kelas mereka, para guru TK Islam Tunas Melati menunjukkan antusiasme dan kreatifitas yang tinggi dalam menerapkan materi pembelajaran bilingual English for Health berbasis bahasa ibu dari ke empat konten area. Mereka sangat menikmati proses pelatihan tahap praktik peer teaching dengan rekan mereka sesame guru di TK Islam Tunas Melati. 


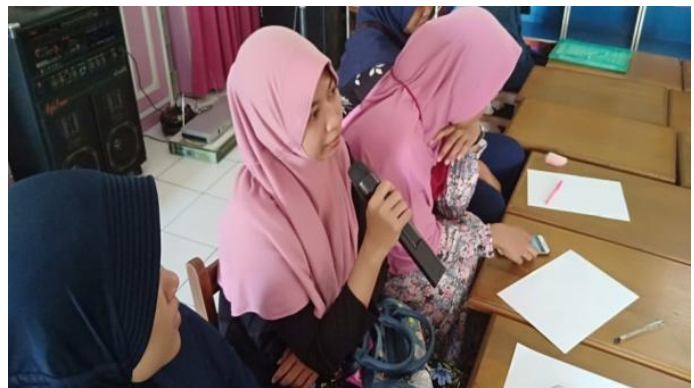

Gambar 6. Diskusi Penyusunan RPP

Hasil dari implementasi tahap tiga pada Mitra kedua yaitu TK Amanah Al Kafalah sebagai kelanjutan dari tahap penyusunan RPP adalah Praktik Peer Teaching menunjukkan hasil yang sangat menarik dan mememuaskan. Para Guru menikmati suasana belajar praktek mengajar dengan sesame rekan kerja dengan penuh semangat dan kreatifitas. Dalam tahap ini, dimana para guru praktik mengajar sebagai simulasi sebelum mereka menerapkkannya di kelas kelas mereka, para guru TK Amanah Al Kafalah menunjukkan antusiasme dan kreatifitas yang tinggi dalam menerapkan materi pembelajaran bilingual English for Health berbasis bahasa ibu dari ke empat konten area saat praktek mengajar dengan rekan mereka. Selama pelatihan pada tahap ini, para guru TK Amanah Al Kafalah sangat menikmati proses pelatihan tahap praktik peer teaching dengan rekan mereka serta memberikan refleksi diri apa yang dirasa kurang pada saat tahap II ini diimplementasikan.

\section{Tahap IV (Tahap Praktik Classroom Practice)}

Setiap guru pada tahap ini adalah kelanjutan dari tahap sebelumnya dimana guru melakukan praktek pembelajaran bilingual English for Health berbasis bahasa ibu dari ke empat konten area dengan rekan mereka sendiri di kelas mereka masing-masing. Teknik pembimbingan dan pendampingan dilakukan untuk mengetahui tingkat pemahaman guru terhadap bagaimana penerapan RPP tentang pembelajaran bilingual English for Health berbasis bahasa ibu dari ke empat konten area yang diterapkan dalam bentuk pembelajaran tentang pembelajaran bilingual English for Health berbasis bahasa ibu dari ke empat konten area yang diintegrasikan dalam proses pengajaran di sekolah mereka sendiri, yakni dalam bentuk:

a) Tim pelaksana pengabdian pada masyarakat melakukan pemantauan dan evaluasi ke sekolah-sekolah tempat praktik guru menerapkan pembelajaran bilingual English for Health berbasis bahasa ibu dari ke empat konten area,

b) Melakukan bimbingan dan pendampingan di luar sekolah seperti melalui telepon dan e-mail, 
c) Guru dapat melakukan konsultasi dengan tim pelaksana (instruktur) di kampus Universitas PGRI Semarang jika diperlukan.

Hasil dari implementasi tahap IV sebagai tindak lanjut dari tahap sebelumnya yaitu tahap praktik peer teaching, maka pada tahap ini guru sudah cukup berhasil dan memuaskan dalam implementasi pembelajaran bilingual English for Health berbasis bahasa ibu dari ke empat konten area di kelas mereka. Anak didik mendapatkan pemahaman akan pentingnya kesehatan, pentingnya meningkatkan ketrampilan sosial dan emosional, meningkatkan pengetahuan tentang Kebugaran dan Nutrisi, Keamanan, Pertolongan Pertama, dan Mencegah cedera/kecelakaan kecil, mengontrol dan menjaga kesehatan supaya tidak mudah jatuh sakit.

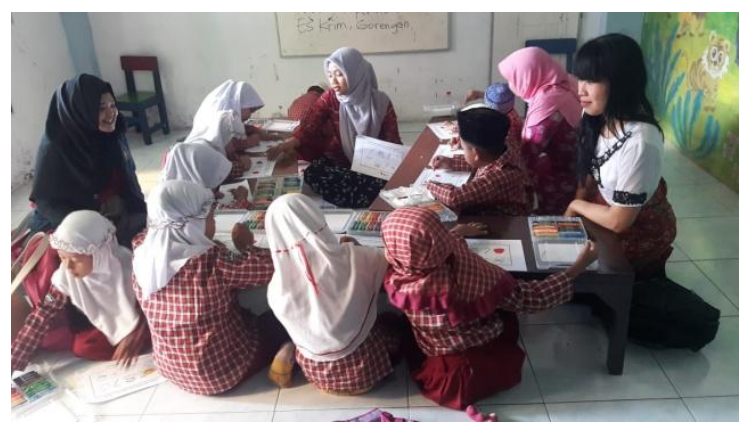

Gambar 7. Praktik bersama siswa TK

Hasil dari implementasi tahap IV yang diterapkan di TK Amanah Al Kafalah merupakan tindak lanjut dari tahap sebelumnya yaitu tahap praktik peer teaching, maka hasil yang dapat dilihat pada tahap ini adalah kemampuan guru yang sudah cukup berhasil dan memuaskan dalam implementasi pembelajaran bilingual English for Health berbasis bahasa ibu dari ke empat konten area di kelas mereka dengan persiapan yang cukup baik dalam ketrampilan bahasa terkait dengan pengucapan bahasa Inggris. Para Guru di TK Amanah Al Kafalah mampu membuat anak didik mendapatkan pemahaman akan pentingnya kesehatan, pentingnya meningkatkan ketrampilan sosial dan emosional, meningkatkan pengetahuan tentang Kebugaran dan Nutrisi, Keamanan, Pertolongan Pertama, dan Mencegah cedera/kecelakaan kecil, mengontrol dan menjaga kesehatan supaya tidak mudah jatuh sakit. Anak anak sangat menikmati proses belajar yang didesain sangat menarik dan menyenangkan berdasarkan kemampuan dan kreatifitas guru TK Amanah Al Kafalah ketika menerapkan pembelajaran bilingual English for Health berbasis bahasa Ibu.

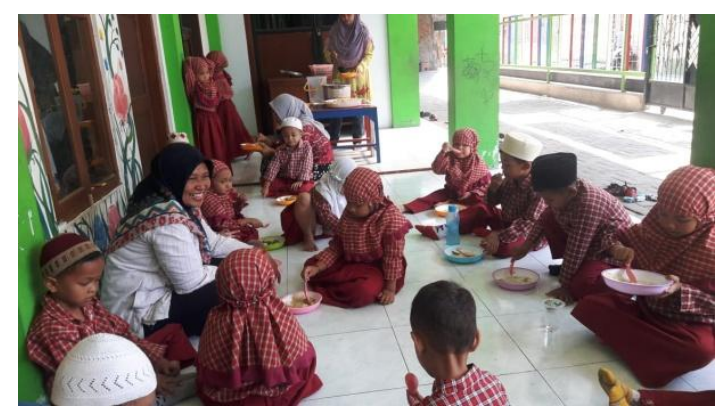

Gambar 8. Tahap V ( Tahap Diskusi \& Refleksi Diri) 
Pada tahap ini adalah tahap diskusi dan refleksi diri sekaligus sharing dari masing-masing guru tentang kelebihan dan juga kekurangan terhadap pembelajaran bilingual English for Health berbasis bahasa ibu dari ke empat konten area sebagai bagian dari pelatihan dan pengembangan pembelajaran bilingual English for Health berbasis bahasa ibu dari ke empat konten area yang diterapkan di sekolah mereka. Bimbingan dan pendampingan pada tahap ini dilakukan di kampus TK Islam Tunas Melati Semarang dan juga kampus TK Amanah Al Kafalah Semarang.

Tahap 1 sudah dilakukan dan sudah tuntas dengan minat peserta yang cukup antusias mengikuti pelatihan dan pengembangan pembelajaran bilingual English for Health berbasis bahasa ibu dari ke empat konten area bagi guru TK Islam Tunas Melati Semarang. Peserta pelatihan tidak hanya dari guru dan staff di lingkungan PAUD akan tetapi anggota komite sekolah juga ikut berpartisipasi dalam rangkaian acara pelatihan yang diadakan oleh tim pengabdi.

Para peserta menjadi lebih memahami arti dari pembelajaran bilingual English for Health berbasis bahasa ibu dari ke empat konten area bahwa sangatlah penting peran guru PAUD dalam memaksimalkan potensi anak agar dapat mengembangkan kemampuan untuk membentuk hubungan yang kuat dengan yang lain, mengekspresikan dan mengontrol emosi, mengeksplorasi dunia di sekitar mereka dan meningkatkan kemampuan problem-solving. Guru PAUD juga diharapkan untuk lebih meningkatkan pula perkembangan kecerdasan anak dan meningkatkan kemampuan mereka dalam menjaga diri dan mampu mengambil keputusan apa yang harus dilakukan ketika menemukan barang barang yang membahayakan ataupun saat terluka. Selain itu, adalah tugas kita sebagai orang tua, orang dewasa, guru, dan penjaga anak untuk mendidik anak agar mampu mengontrol dan menjaga kesehatan supaya tidak mudah jatuh sakit dimana anak diperkenalkan bagaimana menjaga kesehatan dan apa efek yang akan terjadi apabila mereka tidak berusaha untuk menjaga kesehatan badan mereka

Selain dari pada itu, para peserta juga lebih memahami apa itu pembelajaran bilingual English for Health berbasis bahasa ibu dari ke empat konten area dengan memaparkan berbagai macam contoh terkait dengan segala pengetahuan dan ketrampilan tentang kesehatan dan gizi serta kemandirian anak usia dini . Anak akan diajarkan bagaimana mengembangkan ketrampilan social dan 
emosi mereka sehingga mereka akan memiliki pondasi kesehatan yang kuat dan meningkatkan ketrampilan social dan emosi dalam berteman, mengikuti intruksi, mengontrol emosi, mengatasi masalah, dan fokus terhadap tugas dan kegiatan yang diberikan. Anak usia dini juga akan belajar bagaimana memilih makanan yang sehat dan bergizi yang dapat menunjang kebugaran tubuh dan kecerdasan mereka. Selain itu anak juga akan belajar dan berlatih bagaimana menggunakan $\mathrm{P} 3 \mathrm{~K}$ serta memahami dan berlatih menjaga diri supaya tidak terluka dan mengalami kecelakaan. Disamping itu, meningkatkan ketrampilan anak untuk dapat menjaga kesehatan agar tidak mudah jatuh sakit adalah salah satu konten area yang harus di terapkan oleh guru PAUD di dalam maupun di luar pelajaran kelas.

Penting untuk dipahami, khususnya sebagai orang dewasa baik sebagai guru, staff, maupun orangtua, bahwa anak-anak membutuhkan orang dewasa untuk mengembangkan ketrampilan sosial dan emosional mereka, mengembangkan kemampuan pemahaman akan gizi dan kebugaran, mempelajari bagaimana menjaga diri supaya terhindar dari kecelakaan, serta menjaga kesehatan supaya tidak gampang jatuh sakit.

Selanjutnya pada tahap dua adalah tahap pelatihan. Dalam tahap ini peserta berlatih menyusun RPP tentang pembelajaran bilingual English for Health berbasis bahasa ibu dari ke empat konten area sebagai tindak lanjut dari tahap pertama. Peserta pelatihan terdiri dari guru, staff, dan komite sekolah. Mereka cukup antusias menyusun RPP yang pada minggu berikutnya dapat dipraktekkan di kelas sebagai acuan untuk menerapkan program pembelajaran bilingual English for Health berbasis bahasa ibu dari ke empat konten area di sekolah. Para peserta berlatih peer teaching seperti halnya yang tertera dalam lesson plan. Mereka mengajar peserta lain seolah olah seperti anak didik mereka sendiri. Dalam peer teaching, media pembelajaran yang dipakai adalah boneka tangan, gambar, objek asli, realia, dsb. Berikut ini adalah salah satu lesson plan yang dipraktekkan dalam tahap dua yaitu tahap pelatihan.

Tahapan pelatihan dan pengembangan pembelajaran bilingual English for Health berbasis bahasa ibu dari ke empat konten area di TK Islam Tunas Melati Semarang selanjutnya adalah tahap tiga yaitu praktik peer teaching. Dilanjutkan dengan tahap ke empat yaitu tahap praktik di kelas dimana lesson plan di terapkan di kelas dan yang bermain peran dalam tema pembelajaran bilingual English for Health berbasis bahasa ibu dari ke empat konten area adalah anak anak usia dini. Dengan 
menggunakan salah satu metode pembelajaran yaitu bermain peran, maka anak usia dini akan berlatih memerankan bagaimana kenalan dengan teman baru, apa yang dilakukan ketika melihat teman yang sedih, apa yang dilakukan ketika ada teman yang memakan permen, apa yang dilakukan ketika melihat teman yang tidak mencuci tangan terlebih dahulu sebelum makan, dan seterusnya. Anak usia dini akan berlatih memahami bagaimana mengembangkan ketrampilan emosi dan sosial mereka, meningkatkan gizi dan kebugaran mereka, mengenal P3K dan penggunaannya, menjaga diri dari kecelakaan, dan menjaga kesehatan supaya tidak mudah jatuh sakit. Dan mereka juga akan belajar bermain peran sebagai pembeli dan penjual buah, anak yang menyebrang jalan, anak yang sakit, dan lain sebagainya.

Tahap terakhir dari program pelatihan dan pengembangan pembelajaran bilingual English for Health berbasis bahasa ibu dari ke empat konten area berbasis sekolah adalah tahap diskusi dan refleksi diri sekaligus sharing dari masingmasing guru tentang kelebihan dan juga kekurangan terhadap pembelajaran bullying sebagai bagian dari pelatihan dan pengembangan pembelajaran bilingual English for Health berbasis bahasa ibu dari ke empat konten area yang diterapkan di sekolah mereka. Bimbingan dan pendampingan pada tahap ini dilakukan di kampus TK Islam Tunas Melati Semarang dan juga kampus TK Amanah Al Kafalah Semarang. Dalam tahap ini adalah tahap diskusi keberhasilan dan permasalahan selama praktek penerapan pembelajaran bilingual English for Health berbasis bahasa ibu dari ke empat konten area di kelas.

\section{SIMPULAN DAN SARAN}

Program pembelajaran bilingual English for Health berbasis bahasa ibu dari ke empat konten area ini bukan pekerjaan kepala sekolah secara tunggal, akan tetapi ini adalah karya kolaboratif dari semua elemen sekolah yang terintegrasi dengan proses pembelajaran di kelas yang secara bersama sama dan terintegrasi dengan kurikulum dan juga orang tua sebagai lingkungan keluarga yang paling kecil. Perilaku sadar akan kesehatan, sadar akan pentingnya mengatur diri sendiri, sadar sosial, ketrampilan sosial, dan sadar akan tanggungjawab yang muncul di sekolah sangat erat kaitannya dengan pola pola asuh dan komunikasi yang terjadi dan diterapkan di rumah. Dengan demikian peran orang tua sangat penting dalam keberhasilan program pembelajaran bilingual English for Health berbasis bahasa ibu dari ke empat konten area ini. 
Materi yang digunakan dalam berbasis bahasa ibu dari ke empat konten pembelajaran bilingual English for Health berbasis bahasa ibu dari ke empat konten area juga bisa diterapkan di rumah di mana orang tua dapat membaca cerita bertema pembelajaran bilingual English for Health berbasis bahasa ibu dari ke empat konten area dan merangsang perkembangan sosial anak-anak dengan bertanya bagaimana berperilaku kepada teman-teman lain dan bagaimana bersimpati kepada orang lain terkait dengan kesehatan diri sendiri dan juga lingkungan.

Siswa dalam hal ini adalah anak usia dini sebagai subjek maupun objek dari program pembelajaran bilingual English for Health berbasis bahasa ibu dari ke empat konten area ini harus dilibatkan secara aktif mulai dari perencanaan, implementasi hingga evaluasi program. Hal ini bertujuan untuk memberikan pembelajaran pengalaman kepada siswa untuk pemerolehan makna yang tak terlupakan sebagai dasar perilaku mereka. Komunitas yang lebih luas juga tidak lepas dari sekolah sebagai institusi pendidikan. Hal ini karena masyarakat merupakan tempat dimana siswa akan menerapkan semua hal yang dipelajari di sekolah yang pada akhirnya akan direalisasikan sebagai dedikasi dalam dan kepada masyarakat.

Oleh karena itu, program pembelajaran bilingual English for Health area idealnya juga merangkul unsur masyarakat sehingga tercipta bentuk kerjasama dua arah. Dua arah di sini berarti sekolah dapat memberikan pendidikan dan mengajak masyarakat umum untuk bersama-sama mengembangkan kehidupan yang sehat dan bugar yang dapat diterapkan sebagai bagian dari program pembelajaran bilingual English for Health berbasis bahasa ibu dari ke empat konten area dalam program kemitraan masyarakat selanjutnya. Sebaliknya, masyarakat atau institusi yang ada dapat merangkul sekolah untuk berpartisipasi dalam keprihatinan yang sama untuk menciptakan Indonesia yang sehat, cerdas, damai, aman dan sejahtera di semua lapisan masyarakat. Program pembelajaran bilingual English for Health berbasis bahasa ibu dari ke empat konten area harus dijalankan secara konsisten dimanapun dan kapanpun dan dengan siapa saja yang terlibat dalam komunitas sekolah atau masyarakat.

\section{UCAPAN TERIMA KASIH}

Terima kasih kepada Kemenristek Dikti yang telah mendanai kegiatan PKM Pelatihan dan Pengembangan Pembelajaran English for Health Berbasis Bahasa Ibu Bagi Guru Paud Kota Semarang. Terima kasih kami ucapkan 
pula untuk LPPM Universitas PGRI Semarang atas segala fasilitas yang diberikan. \{Citation $\}$

\section{DAFTAR PUSTAKA}

Ball, J. (2010). Educational equity for children from diverse language backgrounds: mother tongue-based bilingual or multilingual education in the early years: summary.

Benson, C. (2005). The importance of mother tongue-based schooling for educational quality. commissioned study for EFA Global Monitoring Report.

Castro, D. C., Ayankoya, B., \& Kasprzak, C. (2011). The New Voices= Nuevas Voces Guide to Cultural and Linguistic Diversity in Early Childhood/The New Voices= Nuevas Voces Facilitator's Guide to Cultural and Linguistic Diversity in Early Childhood. Brookes Publishing Company. PO Box 10624, Baltimore, MD 21285.

Chen, Y., \& Li, H. (2009). Mother's education and child health: Is there a nurturing effect? Journal of health economics, 28(2), 413-426.

Cohen, J. (2006). Social, emotional, ethical, and academic education: Creating a climate for learning, participation in democracy, and well-being. Harvard educational review, 76(2), 201-237.

Desjardins, R., \& Schuller, T. (2006). Measuring the effects of education on health and civic engagement.

Evers, T. (2011). Wisconsin department of public instruction. Retrieved July, 16, 2011..

Setyaji, A., Suneki, S., dan Ambarini, R. 2017. Pengembangan Model Pembelajaran English for Math Berbasis Kearifan Lokal dengan Pendekatan Konstruktivisme di PAUD Kota Semarang. Supported by DRPM Kemenristek Dikti. Semarang : LPPM Universitas PGRI Semarang.

Suneki, Sri., Ambarini, Ririn., dan Destriani, Dwi. 2012. "Peningkatan Character Building dan Kreativitas Anak Usia Dini Melalui TPR Warm Up Game Pada Anak Didik Kelompok A TK Doa Ibu Kecamatan Tembalang Semarang”. Semarang: LPPM IKIP PGRI Semarang. (tidak diterbitkan).

Suneki, Sri., Wardoyo, L. Subur., dan Ambarini, $\quad$ Ririn. 2013. Pengembangan Perangkat Pembelajaran Anak Usia dini melalui Game Edukasi Fairy Tales Berbasis Pendidikan Moral. 
Semarang: LPPM IKIP PGRI

Semarang. (tidak diterbitkan).

UNESCO. 2014. Enhancing Teacher

Education for Bridging the Education Quality Gap in Africa. Needs Assesment Framework of Teacher Training and Development to Ensure Education for All (EFA). Republic of Uganda. Ministry of Education and Sports Uganda National Commission for UNESCO. UNESCO-China Fundin-Trust Project.

Van Roekel, D. 2008. Parent, Family, Community Involvement in Education. NEA Education Policy and Practice Departmet. Center for Great Public Schools. NW. Washington. D.C.

Wardoyo, Laksmono, S., Ambarini, Ririn., dan Destriani, Dwi. 2012. Peningkatan Role Playing dalam Pembelajaran Bahasa Inggris Berbasis Beyond Center and Circle Time (BBCT) pada Anak Didik PAUD Al Azam Semarang. Semarang: LPPM IKIP PGRI Semarang. (tidak diterbitkan).

Zelasko, N., \& Antunez, B. 2000. If your child learns in two languages. National Clearinghouse for Bilingual Education. Retrieved from http://www.ncela.gwu.edu/files/upl oads/9/IfYourChild LearnsInTwoLangs_English.pdf 